\title{
Design of low-rise buildings from thin-walled steel frame structures
}

\author{
Olga Umnova ${ }^{1}$, Dmitry Tuev ${ }^{1}$ and Timur Giyasov ${ }^{2, *}$ \\ ${ }^{1}$ Tambov State Technical University, 106, Sovetskayaul., Tambov, 392000, Russia \\ ${ }^{2}$ Moscow State University of Civil Engineering, Yaroslavskoe shosse, 26, Moscow, 129337, Russia
}

\begin{abstract}
Addressing sustainable development challenges, Russia is seeking new opportunities for the use of thin-walled cold-cast structures to meet the requirements of cost-effectiveness, eco-friendliness, and rapid construction. The study aims to explore the possibilities of design and calculation of low-rise buildings erected from lightweight thin-walled steel structures using frame construction technology. The design solutions for the roof, walls, floors, and foundation are exemplified using concrete examples. The load capacity off framing studs, roof beams, and floor slabs was calculated. Three methods were used for calculation - Eurocode 3, direct strength test, and ultimate load test in compliance with AISI standards.
\end{abstract}

\section{Introduction}

The use of cold-formed structures in the frame construction is not a novel technology, neither in the world nor in Russia. The technology was developed several decades ago.

For the first time, cold-cast structures were used in construction in the 1950s [1]. The first buildings of thin-walled steel structures were erected in North America and Great Britain. They possessed a number of distinctive features, includingcost-effectiveness, energy efficiency, and environmental friendliness.

In 1933, at the World Exhibition in Chicago, the "house of the future" was presented; it was made from steel frame structures. The Architect Howard T. Fisher, the project manager, borrowed the engineering ideas from research into steel for the manufacture of rail cars.

In 1939, the American Iron and Steel Institute funded the research project Cornell University. The results of the study were published in 1946, and the first edition of AISI "Specification for the Design of Light Gage Steel Structural Members" was published. With the release of the first specifications, systematic development and use of steel thin-walled structures began in America.

In Russia, the beginning of construction from lightweight thin-walled steel structures is associated with the study of roll-formed structures (roll-forming) in the engineering sector. In the 1970s, the directives of the 23rd CPSU Congress set an ambitious goal of reducing metal consumption by $20-25 \%$; it was planned to achieve this goal through the use of thinwalled structures in construction. According to the Central Research Institute of Building Structures and the "Ukrproektstalkonstruktsiya" Institute, metal savings in the production of

\footnotetext{
*Corresponding author: timrus64@mail.ru
} 
trusses from cold-formed elements were estimated at 10-30\%, while the labor costs decreased by $50 \%$, and the cost was reduced by $25 \%$.

The popularity of the thin-walled steel structures in the USSR is confirmed by the fact that in 1980 the efficiency of replacement of high-quality rolled metal products with thinwalled cold-formed structures in the construction of facilities resulted in thesavingsof 200 million rubles and 1.7 million tons of metal.

With all the obvious advantages, this technology was not been widely developed in Russia due to the lack of a regulatory framework.

Currently, this technology isin the focus of attention of engineers, and the possibility of using thin-walled cold-formed elements in the building structures is explored [2 - 5]. In addition to the properties ofcold-formedstructuresmentioned above, resistance to corrosion and thermal insulation were described in a number of publications [6 - 10]. From 2012 to 2018, the volume of construction usingthin-walled steel structures in Russia grew by about 4 times. Also, the interest in the calculation of cold-formedstructural elements has led to the development and wider dissemination of methods for determining their bearing capacity.

In this article, we will describe a comprehensive method for designing a low-rise building from thin-walled steel structures. In the process, we will perform the modeling of the stressstrain state of the entire building in the SCAD Office program and the modeling of the behavior of individual elements in the CUFSM program, and estimate the bearing capacity of different structural elements using methods of Eurocode 3 and AISI specifications.

\section{Materials and methods}

We consider the basics of designing residential low-rise buildingsmade from thin-walled steel structural elements, using frame technology. The following basic structural elements are used in low-rise building design:

- studs (external and internal);

- floorbeams;

- roof structures (beams or trusses);

- linking elements (upper and lower edges of wall panels, struts and braces).

For structures of the outer contour of buildings, the so-called thermal profile, or perforated profile is used, in which a heat flow elongation occurs due to cuttings, which leads to better thermal insulation properties. In bending structures, it is preferable to use structural elements with stiffeners due to their significant spans.

Since the "skeleton frame" building from thin-walled steel structures is a multi-element, interconnected system, the static calculation should be performed in special software systems to account for the interaction of the maximum possible number of factors.

One of possible methods of design of a thin-walled steel frame low-rise building is shown below. A three-storey residential building was used as an example; Figures 1,3 show the plan extract and the cross-sectional view. In the structural design of the building, the following structural elementswereused according to the specifications of "LASAR" company [11], Fig. 2: 


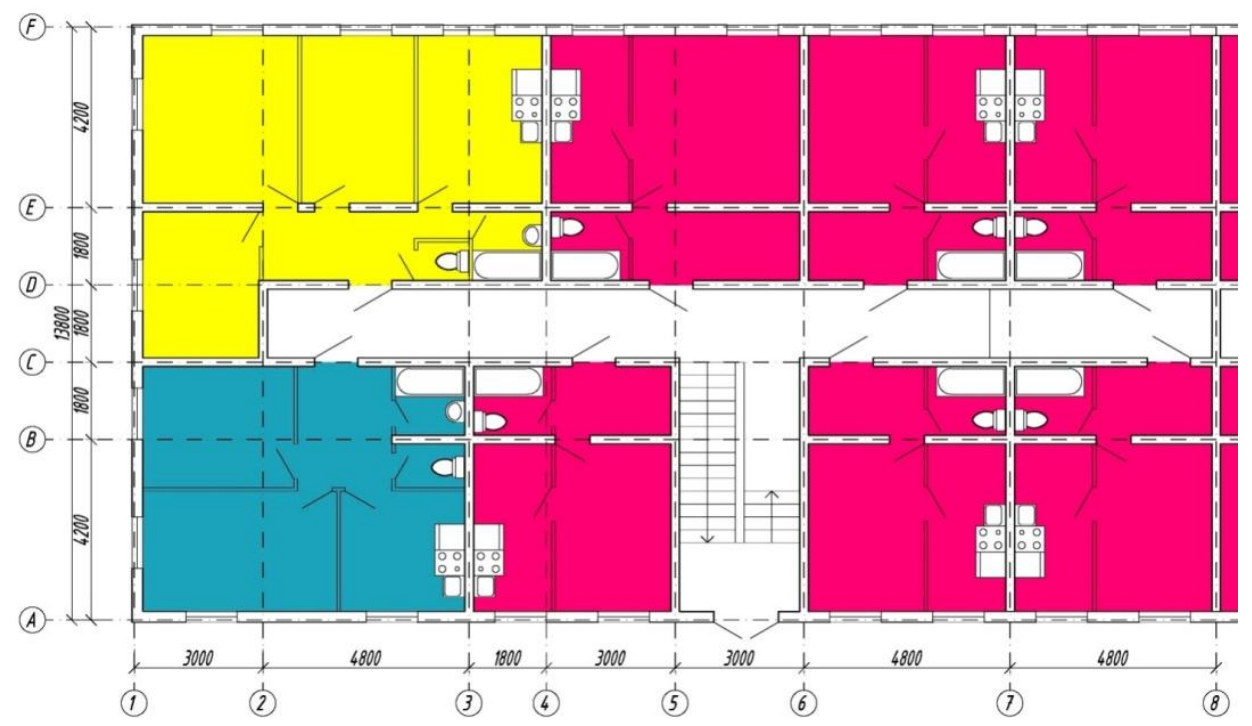

Fig. 1. Plan extract. A three-room apartment is in yellow; a two-room apartment is in blue; a oneroom apartment is in red.

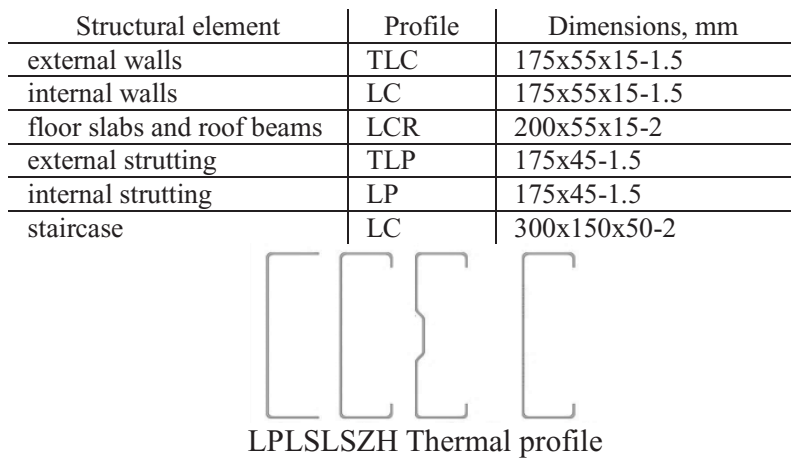

Fig. 2. Shapes of profiles used, *T- ThermalProfile,OOO "LASAR" (L), C- shapedsection (S), high rigidity $(\mathrm{R}), \mathrm{P}$ - shaped section $(\mathrm{P})$.

Spacing between studsandroofbeamswastakenas600 mmfor ease of installation of thermal insulation and sound insulation. The stud height was $3000 \mathrm{~mm}$; the roomheight was 2710 $\mathrm{mm}$. The method of elementconjugation was a pin joint. The structural solution of the building is shown in Figures $4-6$.

The static analysis of the building was made in SCAD Office. Cross-sections were formed in Tonussatellite program. The design scheme of the building was created in the program AutoCad, with the subsequent import into SCAD and is shown in Figure 7. 


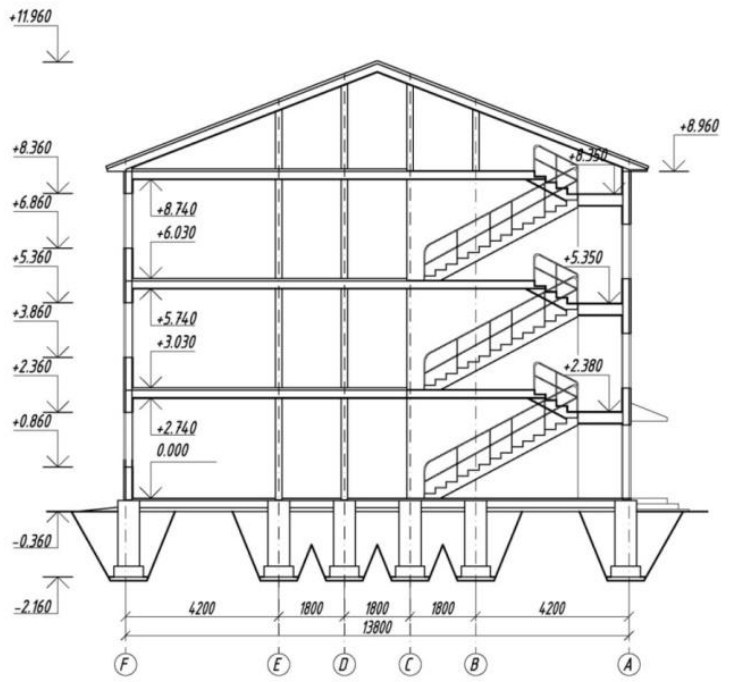

Fig. 3. Cross-sectional view of the building.
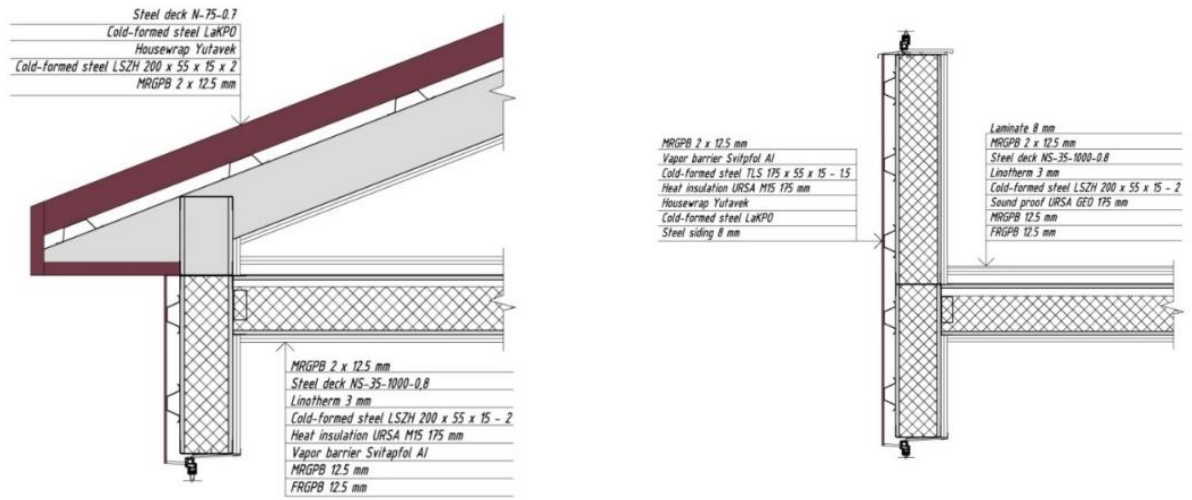

Fig. 4. Designsolution of the roof and attic floor Fig. 5. Design solution of the wall and floor.

\section{Results}

The main results of the static analysis are shownin Figures $8-10$. The maximum compressive forces were $41.72 \mathrm{kN}$, the maximum bending moments were $7.44 \mathrm{kN} \cdot \mathrm{m}$, the maximum horizontal movements were $9.69 \mathrm{~mm}$, the maximum deflection was observed in the roof beams and was $22 \mathrm{~mm}$.

Calculation of the load-bearing capacity of thin-walled rods can be performed in different ways. In this paper, the calculation of studs was made using the Eurocode 3 method [3-5] and the Direct Strength Method (DSM) [6]. The calculation of studs was performed by the- DSM. The calculation of roof beams was carried out jointly by DSM and Eurocode 3. The use of DSM was carried out in accordance with the Load and Resistance 


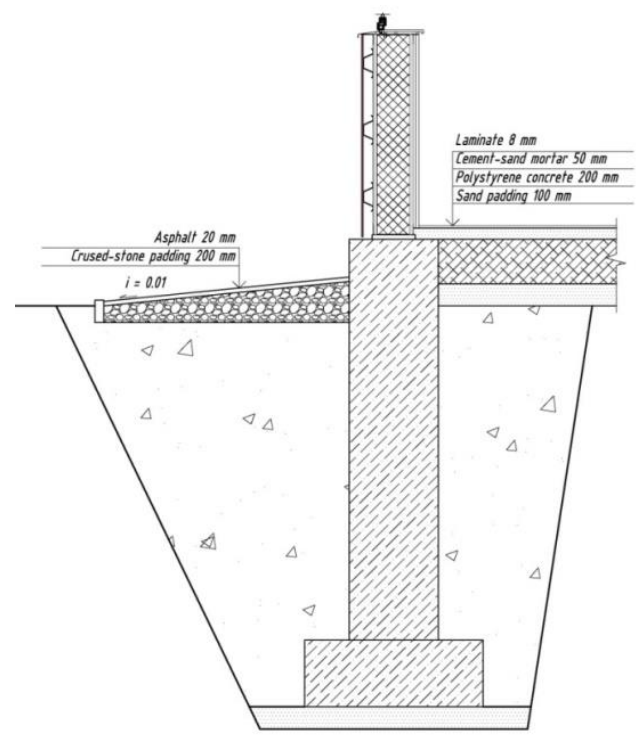

Fig. 6. Design solution of the foundation.
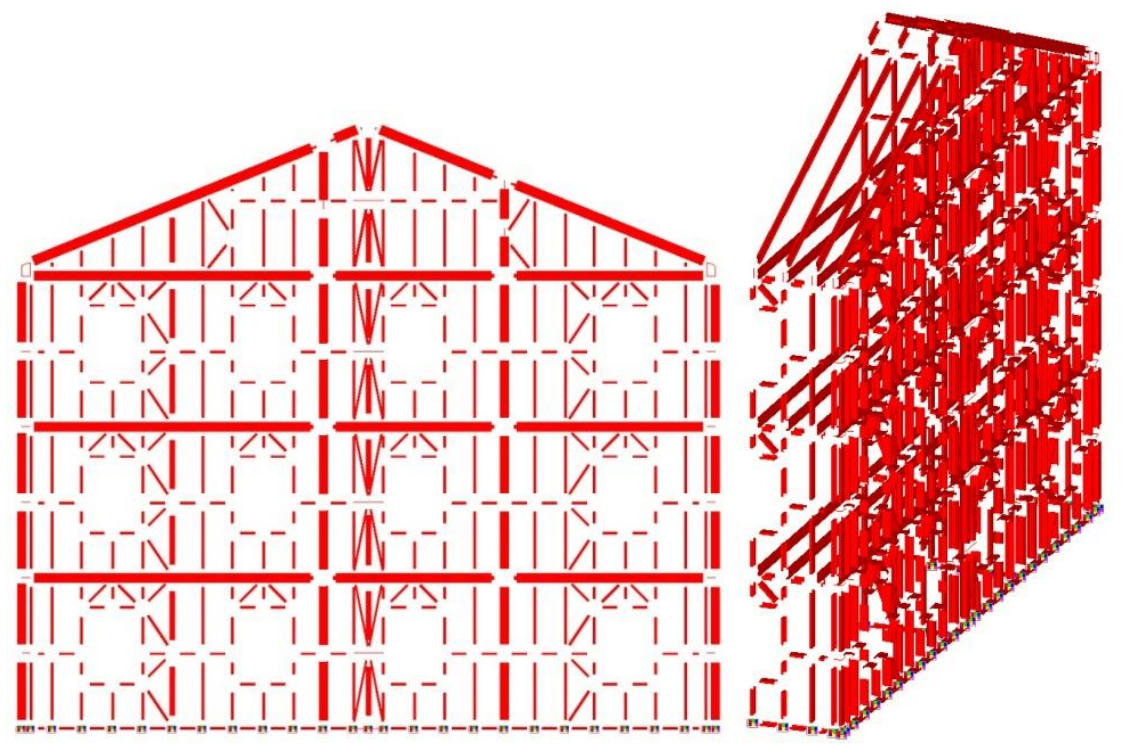

Fig. 7. Design building scheme. Left: view on the digital axis. Right: graphical representation of the scheme taking into account the structural elements.

Factor Design (LRFD) [8]. The determination of the critical forces for DSM was performed using the CUFSM program [8].

For the analysis the following properties of steel we used:

- zinc plated rolled steel grade [23] - 350;

- yieldstress $-f_{y}=333 \mathrm{MPa}$;

- Young's modulus $-E=210000 M P a$;

- Poisson's ratio $-v=0,3$; 
- shear modulus $-G=80770 \mathrm{MPa}$.

The length of elements:

- studs - $3000 \mathrm{~mm}$;

- floor beams - $6000 \mathrm{~mm}$;

- roof beams $-7500 \mathrm{~mm}$.

The results of the calculation are presented in Tables 1-7.
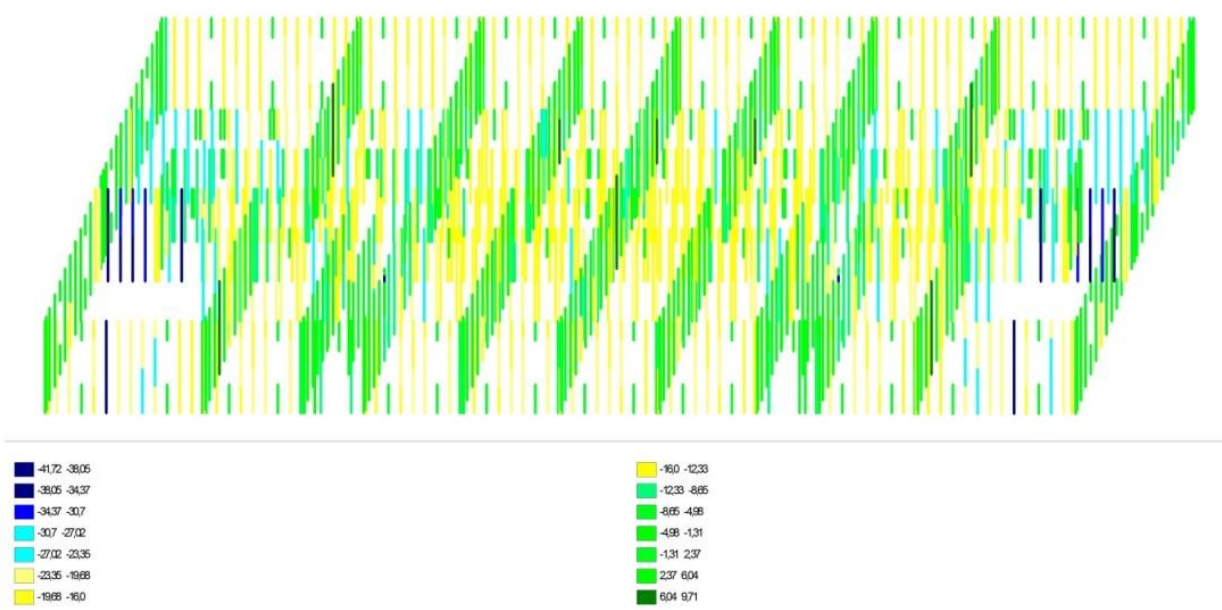

Fig. 8. Longitudinal forces $\mathrm{N}$ inground floor studs, $\mathrm{kN}$.

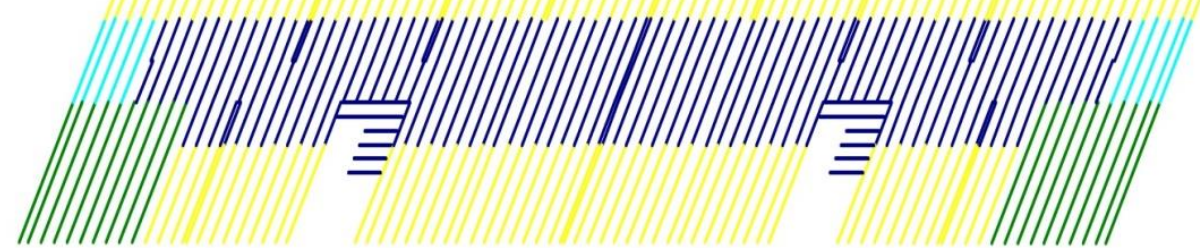

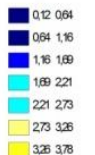

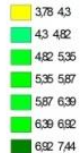

Fig. 9. Bending moments in ground floor beams. 


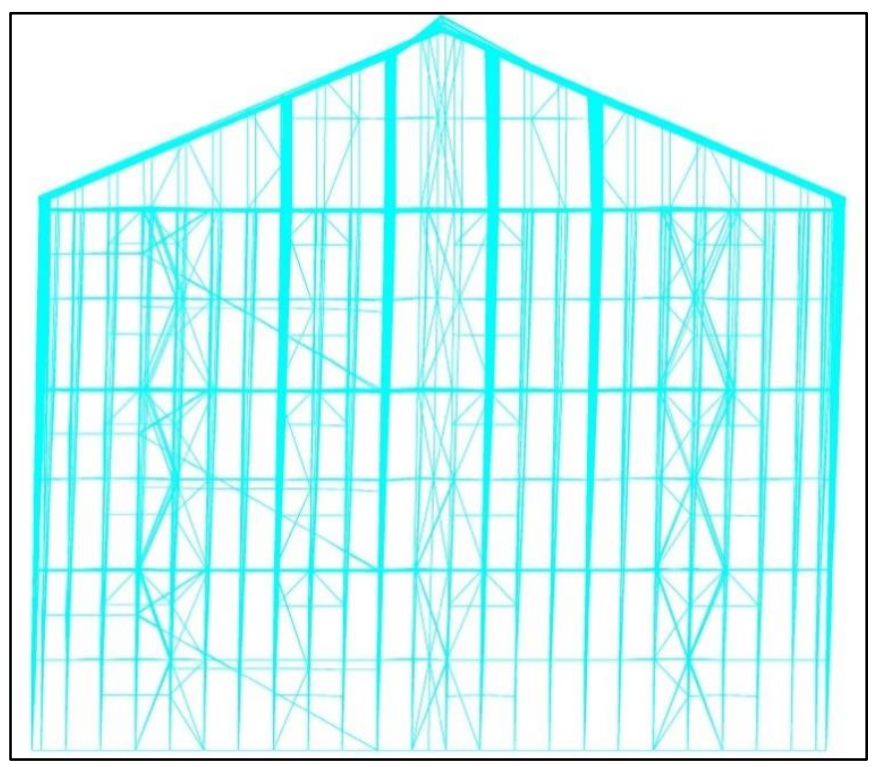

Fig. 10. Deformation scheme.

Table 1. Load bearing capacity of external studs in the Eurocode 3.

\begin{tabular}{|l|c|c|c|}
\hline \multicolumn{1}{|c|}{ Buckling mode } & $\chi$ & $A_{\text {eff }}, \mathrm{mm}^{2}$ & $N_{b, R d}, \mathrm{kN}$ \\
\hline \multicolumn{1}{|c|}{1} & 2 & 3 & 4 \\
\hline Flexural buckling about axis of max stiffness & 0.940 & & 69.94 \\
\hline Flexural buckling about axis of min stiffness & 0.769 & \multirow{2}{*}{229.9} & 57.20 \\
\hline Torsional buckling & 0.728 & & 54.17 \\
\cline { 1 - 2 } \cline { 1 - 1 } & 0.707 & & 52.61 \\
\hline
\end{tabular}

Table 2. Load bearing capacity of external studs in theDSM and LRFD.

\begin{tabular}{|c|c|c|c|c|c|}
\hline Buckling form & $P_{y}, k N$ & $\overline{P_{c r} / P_{y}}$ & $P_{n}, \mathrm{kN}$ & $P_{n, \text { min }}, \mathrm{kN}$ & $\varphi P_{n, \min }, k N$ \\
\hline General buckling & \multirow{3}{*}{149.77} & 1.15 & 104.04 & \multirow{3}{*}{60.6} & \multirow{3}{*}{51.51} \\
\hline Secondary buckling & & 0.23 & 60.6 & & \\
\hline Distortional buckling & & 0.43 & 76.66 & & \\
\hline
\end{tabular}

Table 3. Load bearing capacity of internal studs in the Eurocode 3.

\begin{tabular}{|c|c|c|c|}
\hline Buckling mode & $\chi$ & $A_{e f f}, \mathrm{~mm}^{2}$ & $N_{b, R d}, \mathrm{kN}$ \\
\hline 1 & 2 & 3 & 4 \\
\hline Flexural buckling about axis of max stiffness & 0.943 & \multirow{4}{*}{232.5} & 73.27 \\
\hline Flexural buckling about axis of min stiffness & 0.768 & & 60.88 \\
\hline Torsional buckling & 0.762 & & 59.07 \\
\hline Flexural-torsional buckling & 0.743 & & 57.55 \\
\hline
\end{tabular}

Table 4. Load bearing capacity of internal studs in the DSM and LRFD.

\begin{tabular}{|c|c|c|c|c|c|}
\hline Buckling mode & $P_{y}, k N$ & $P_{c r} / P_{y}$ & $P_{n}, \mathrm{kN}$ & $P_{n, \text { min }}, \mathrm{kN}$ & $\varphi P_{n, \text { min }}, k N$ \\
\hline 1 & 2 & 3 & 4 & 5 & 6 \\
\hline General buckling & \multirow{3}{*}{153,09} & 1.1533 & 106.496 & \multirow{3}{*}{63.04} & \multirow{3}{*}{53.6} \\
\hline Secondary buckling & & 0.243 & 63.04 & & \\
\hline Distortional buckling & & 0.457 & 80.7 & & \\
\hline
\end{tabular}


Table 5. Load bearing capacity of floor beams in the DSM and LRFD.

\begin{tabular}{|c|c|c|c|c|c|}
\hline Buckling mode & $M_{y}, \mathrm{kN} \cdot \mathrm{m}$ & $M_{c r} / M_{y}$ & $M_{n}, \mathrm{kN} \cdot \mathrm{m}$ & $M_{n, \min }, \mathrm{kN} \cdot \mathrm{m}$ & $\varphi M_{n, \text { min }}, \mathrm{kN} \cdot \mathrm{m}$ \\
\hline 1 & 2 & 3 & 4 & 5 & 6 \\
\hline General buckling & \multirow{3}{*}{12.90} & 89.67 & 12.90 & \multirow{3}{*}{12.14} & \multirow{3}{*}{10.93} \\
\hline Secondary buckling & & 3.37 & 12.90 & & \\
\hline Distortional buckling & & 1.77 & 12.14 & & \\
\hline
\end{tabular}

Table 6. Load bearing capacity of roof beams under axial compression in the DSM.

\begin{tabular}{|c|c|c|c|c|c|}
\hline Buckling mode & $P_{y}, k N$ & $P_{c r} / P_{y}$ & $P_{n}, \mathrm{kN}$ & $P_{n, \text { min }}, \mathrm{kN}$ & $\varphi P_{n, \min }, k N$ \\
\hline 1 & 2 & 3 & 4 & 5 & 6 \\
\hline General buckling & \multirow{3}{*}{224.61} & 0.04403 & 8.673 & \multirow{3}{*}{8.67} & \multirow{3}{*}{7.37} \\
\hline Secondary buckling & & 2.7068 & 8.7 & & \\
\hline Distortional buckling & & 0.70877 & 145.5 & & \\
\hline
\end{tabular}

Table 7. Load bearing capacity of roof beams underbendingin the DSM.

\begin{tabular}{|c|c|c|c|c|c|}
\hline Buckling mode & $M_{y}, \mathrm{kN} \cdot \mathrm{m}$ & $M_{c r} / M_{y}$ & $M_{n}, \mathrm{kN} \cdot \mathrm{m}$ & $M_{n, \min }, \mathrm{kN} \cdot \mathrm{m}$ & $\varphi M_{n, \min }, \mathrm{kN} \cdot \mathrm{m}$ \\
\hline 1 & 2 & 3 & 4 & 5 & 6 \\
\hline General buckling & \multirow{3}{*}{12.90} & 89.67 & 12.90 & \multirow{3}{*}{12.14} & \multirow{3}{*}{10.93} \\
\hline Secondary buckling & & 3.37 & 12.90 & & \\
\hline $\begin{array}{l}\text { Distortional } \\
\text { buckling }\end{array}$ & & 1.77 & 12.14 & & \\
\hline
\end{tabular}

The following notation was used in the tables:

$\chi$-buckling modereduction factor;

$A_{\text {eff }}$-effectivecross-section area;

$N_{b, R d}$-structural failure in the Eurocode 3;

$P_{y}, M_{y}$ - yield stress;

$P_{c r}, M_{c r}$-critical buckling load;

$P_{n}, M_{n}$-load bearing capacity in the DSM;

$\varphi$-safetyfactor in theLRFD.

The bearing capacity of the studswas calculated for centrally compressed rods, the capacity of roof beams was calculated for bent elements, the capacity of roof beams was calculated for the section subjected to compression and bending (the critical forces of buckling werecalculated separately for compression and separately for bending):

- studs

$$
\frac{N_{E d}}{\varphi P_{n, \min }}=\frac{41.72}{51.51}=0.81<1
$$

- floor beams

$$
\frac{M_{E d}}{\varphi M_{n, \min }}=\frac{7.44}{10.93}=0.68<1
$$

- roof beams

$$
\left(\frac{N_{E d}}{\varphi P_{n, \text { min }}}\right)^{0.8}+\left(\frac{M_{E d}}{\varphi M_{n, \text { min }}}\right)^{0.8}=\left(\frac{1.66}{7.37}\right)^{0.8}+\left(\frac{4.91}{10.93}\right)^{0.8}=0.83<1
$$

The maximum deflection of thin-walled steel structures according to Eurocode 3 was equal to

$$
f_{u}=L / 300
$$

As can be seen from the above data, all the building elements meet the requirements of Eurocode 3 and AISI standards. 


\section{Conclusions}

In this paper, a method for designing and calculating a low-rise building constructed from thin-walled steel structural elements was described. Possible design solutions of an apartment building wereproposed. The results of calculation of the loadbearing capacity of frame elements arein compliance with the standards: Eurocode 3, DSM and LRFD. The final calculation of the load-bearing frame was made for the minimum parameters, which ensures its higher reliability.

\section{References}

1. Cold-Formed Steel Engineers Institute, cfsei.org/history (2018)

2. D.S. Tuev, O.V. Umnova, Novaya nauka: Strategii i vektory razvitiya: Mezhdunarodnoe nauchnoe periodicheskoe izda-nie (Izhevsk, 2016)

3. G.B. Verzhbovskij, E.V. Kolesova Naukovedenie 3, 1-6 (2012)

4. D.V. Kuzmenko, N.I. Strojprofil' 6, 32-36 (2008)

5. E.N. Zhmarin, Stroitel'stvo unikal'nyh zdanij i sooruzhenij 2, 27-30 (2012)

6. E.N. Popova, N.I. Vatin, Termoprofil'v legkih stal'nyh stroitel'nyh konstrukciyah (SPb, 2006)

7. V.Yu. Kuznecova, Yu.G. Barabanshchikov, Stroitel'stvo unikal'nyh zdanij i sooruzhenij 5(44), 7-18 (2016)

8. V.A. Semko, D.A. Prohorenko, Predotvrashchenie avarij zdanij i sooruzhenij, 1-15 (2011) http://www.pamag.ru/pressa/akm-pnp-lstp

9. A.V. Orlova, E.N. Zhmarin, K.O. Paramonov, Stroitel'stvo unikal'nyh zdanij i sooruzhenij 6(11), 1-13 (2013)

10. M.K. Bronzova Construction of Unique Buildings and Structures 1(28), 74-90 (2015)

11. Russian Standard TU 1121-010-46216359-2015

12. D.S. Shatov, Konechnoelementnoe modelirovanie stal'nyh tonkostennyh perforirovanny stoek: magister-skaya dissertaciya: 270100 (SPb, 2011)

13. V.A. Rybakov, Osnovy stroitel'noj mekhaniki legkih stal'nyh tonkostennyh konstrukcij: ucheb. posobie (Izd-vo Politekhn. un-ta, SPb, 2001)

14. A.O. Gordeeva, Inzhenerno-stroitel'nyj zhurnal 3, 36-46 (2011)

15. V.V. Yurchenko, Inzhenerno-stroitel'nyj zhurnal 8, 38-46 (2010)

16. EN 1993-1-1-2009 Eurocode 3

17. EN 1993-1-3-2009 Eurocode 3

18. EN 1993-1-3-2009 Eurocode 3

19. B. Schafer, Design Manual for Direct Strength Method of Cold-Formed Steel Design (American Iron and Steel Institute - Committee on Specifications, 2002)

20. AISI S100-16 North American Specification for the Design of Cold-Formed Steel Structural Members (2016)

21. ANSI/AISC 360-10 Specification for Structural Steel Buildings (American Institute of Steel Construction, 2010)

22. B.W. Schafer, S. Adany, Proc.18th Inter. Specialty Conference on Cold-Formed Steel Structures (Orlando, Florida, 2006)

23. Russian Standard GOST R 52246-2004 